\title{
Deconstructing Innocence: Reflections from a Public Defender: Can student attorneys accept the paradigm of guilt and continue zealous representation?
}

\section{Geneva Brown}

Assistant Professor of Law

Valparaiso University School of Law, Indiana, USA

\section{Introduction}

I am a true believer. ${ }^{1}$ I was a public defender for nine years and represented thousands of guilty defendants without guilt or emotional angst. The public defender credo is to give zealous representation without consideration for the innocence or guilt of the client. ${ }^{2}$ As a clinical

1 See Minna Kotkin, Creating True Believers: Putting Macro Theory Into Practice, 5 J. Clinical L Rev. 95 (1998). Kotkin argues that Clinical teachers should employ macro theory in their teaching methodology to introduce the idea of "critical lawyering as an over-arching paradigm that will imbue students with skills and a solid theoretical foundation." See also Damon Centola, Robb Willer and Michael Macy, The Emperor's Dilemma: A Computational Model of Self-Enforcing Norms, 110 Am. J. Soc. 4 (2005). The authors describe the true believer as one who believes in the enforcement of a social norm, (in my case, the quality of representation has not defined the guilt or innocence of the client) and the enforcement of the norm is done for the right reason. They note it is better not to comply with the norm than create the illusion of sincerity. As the authors note, "true believers reserve special contempt for imposters." Id.

2 See Charles J. Ogletree, Jr., Beyond Justifications: Seeking Motivations to Sustain Public Defenders, 106 Harv. L. Rev. 1239 (1993); Abbe Smith \& William Montross, The Calling of Criminal Defense, 50 Mercer L. Rev. 443 (1999). 
instructor I must impart ethical and diligent representation to my students. ${ }^{3}$ I found, however, when discussing cases during our weekly case rounds the paradigm of innocence would inevitably become a question for the student attorney. The students imputed guilt and innocence to be mutually exclusive.

Imparting the ethical component of criminal defense - to be competent in having legal knowledge, skill and thoroughness of preparation - to the students was a job I was thoroughly prepared to teach. I found, however, that beyond ethical considerations of representing clients, I needed to deconstruct innocence. ${ }^{4}$ I wanted to present to students a paradigm that guilt or innocence is secondary to servicing the needs of the client and protecting the client's rights through the maze of a convoluted and dispassionate court system. ${ }^{5}$ Creating a dialogue that evolved from loaded terms such as guilt, truth or innocence and creating representation where the focal point became servicing the needs of the client became my goal.

This article examines the impact and the importance of the innocence movement and the unintended effects on criminal defense representation. Part I examines the impact of innocence in my juvenile clinic. Part II proceeds to examine the paradigm of the innocence movement and its

3 See, e.g., Steven Hartwell, Moral Development, Ethical Conduct and Clinical Education, 35 N.Y.L. Sch. L. Rev. 131 (1990); Robert D. Dinerstein, Clinical Scholarship and the Justice Mission, 40 Clev. St. L. Rev. 469 (1992); Fren Quigley, Seizing the Disorienting Moment: Adult Learning Theory and the Teaching of Social Justice in Law School Clinics, 2 Clinical L. Rev. 37 (1995); Minna J. Kotkin, The Law School Clinic: A Training Ground for Public Interest Lawyers in Educating for Justice: Social Values and Legal Education 129 (Jeremy Cooper \& Louise G. Trubek eds., 1997).

4 The concern for the innocent being falsely convicted in the American criminal justice system is a well documented issue. My concern is that the state of being innocent overshadows client-centered representation. See, e.g., Brandon Garrett, Judging Innocence, 108 Colum. L. Rev. 55 (2008) (reviewing the empirical study conducted to determine how people who were ultimately exonerated were handled by the American criminal justice system); Darryl K. Brown, The Decline of Defense Counsel and the Rise of Accuracy in Criminal Adjudication, 93 Cal. L. Rev. 1585, 1590-91, 1644 (2005) (describing impact of wrongful convictions on criminal trials and investigations); Brandon Garrett, Aggregation in Criminal Law, 95 Cal. L. Rev. 383, 449-50 (2007) (exploring systemic reform efforts in courts and innocence commissions aiming to remedy wrongful convictions); Brandon Garrett, Innocence Harmless Error, and Federal Wrongful Conviction Law, 2005 Wis. L. Rev. 35, 82-85, 99-110 (describing possible transformative effect of wrongful conviction cases on underlying criminal procedure rules); Daniel S. Medwed, Innocence Lost... and Found: An Introduction to The Faces of Wrongful Conviction
Symposium Issue, 37 Golden Gate U. L. Rev. 1, 1 (2006) (introducing symposium); Richard A. Rosen, Reflections on Innocence, 2006 Wis. L. Rev. 237 (introducing symposium and discussing Criminal Justice in the Age of Innocence).

5 See generally, Mary Jo Eyster, Analysis of Sexism in Legal Practice: A Clinical Approach, $38 \mathrm{~J}$. Legal Educ. 183 (1988) (discussing the problems of sexism and strategies used to address the problems); Shelley Gavigan, Twenty-Five Years of Dynamic Tension: The Parkdale Community Legal Services Experience, 35 Osgoode Hall L.J. 443, 467 (1997) (discussing anti-racism skills); Bill Ong Hing, Raising Personal Identification Issues of Class, Race, Ethnicity, Gender, Sexual Orientation, Physical Disability, and Age in Lawyering Courses, 45 Stan. L. Rev. 1807 (1993); Michelle S. Jacobs, People from the Footnotes: The Missing Element in Client Centered Counseling, 27 Golden Gate U. L. Rev. 345, 348 (1997) (exploring how race neutral-training of interviewing and counseling skills may lead to continued marginalization of clients of color); Michelle S. Jacobs, Full Legal Representation for the Poor: The Clash Between Lawyer Values and Client Worthiness, 44 How. L.J. 257 (2001) (explaining how law students engage in value ranking); Michelle S. Jacobs, Clinical Essay: Legitimacy and the Power Game, 1 Clinical L. Rev. 187 (1994) (confronting the belief of many clinical instructors that supervisory relationships should be characterized by cooperative, equal, non-hierarchical organization); Rose Voyvodic \& Mary Medcalf, Advancing Social Justice Through an Interdisciplinary Approach to Clinical Legal Education: The Case of Legal Assistance of Windsor, 14 Wasg. U. J.L. \& Pol'y 101 (2004). 
impact on the criminal justice system. Part III examines the rise of Innocence Projects and the effect on clinical legal education. Part IV deconstructs the importance of innocence and the substantive and procedural problems with innocence. Part $\mathrm{V}$ concludes the article with an assertion of the importance of zealous representation regardless of innocence or guilt.

\section{A Question of Innocence}

In my juvenile justice clinic, we began to represent two juvenile females who were both charged with prostitution. ${ }^{6}$ Both girls, Jill and Dana, denied the charges at the initial hearing. ${ }^{7}$ I paired a student attorney and a student social worker to represent both girls. I immediately noticed an affinity the student attorney and the social worker had for Jill. Jill vehemently denied the charges. Jill spoke softly with a slight southern drawl and was the model of courtesy. Dana was more of an enigma. She was not forthcoming. Dana was not so emphatic in her denials but she refused to enter an admission to a prostitution charge. During case rounds we discussed the similarities and differences of Jill's and Dana's cases.

Assumptions were immediately being made about Jill. The students created a narrative of a runaway whose mother abandoned her and who was being exploited by a dangerous boyfriend and possible pimp. ${ }^{8}$ The police detained Jill for being a minor in a casino in the company of a man they presumed was her pimp. Dana did not have a narrative. The students reviewed the police reports. Undercover vice detectives brought Dana and her teenaged companion to a hotel room and arrested both of them after drinks and conversation. Dana's exploitation was ambiguous as was her innocence.

The moral ambiguity in Dana's case was compounded by her refusal to accept plea bargains. The magistrate would only accept an admission to the charge or a trial. ${ }^{9}$ We were going to have to try

6 The treatment of teenaged prostitutes by the adult criminal or juvenile delinquency system motivated the students to keep our clients from being a party in the system any longer than necessary. For further discussion see Geneva O. Brown, Little Girl Lost: Las Vegas Metro Police Vice Division and the Use of Material Witness Holds Against Teenaged Prostitutes, 57 Cath. U. L. Rev. 471 (2008)

7 The names are changed to protect the confidential status of juvenile clients.

8 I would be remiss to dismiss the importance of narrative in representing clients but the students' narrative emphasized innocence. See e.g., Sarah Buel, Effective Assistance of Counsel for Battered Women Defendants: A Normative Construct, 26 Harv. Women's L.J. 217 (2003) (describing how lawyers must address race and class issues of battered woman for effective representation); Leigh Goodmark, Telling Stories, Saving Lives: Battered Mothers' Testimony Project, Womens' Narratives and Court Reform, 37 Ariz. St. L.J. (2005) (describing the methodology, finding and conclusions of the Battered Mothers' Testimony Project); V. Puslani Enos, Lois Kanter, Who's Listening: Introducing Students to Client-Centered, Client-Empowering and
Multidisciplinary Problem Solving In a Clinical Setting, 9 Clinical L. Rev. 83 (2002) (describing the use of listening abilities of students involved in the Boston Medical Center Domestic Violence Project); John B. Mitchell, Narrative and Client Centered Representation: What is a True Believer to do When His Two Favorite Theories Collide, 6 Clinical L. Rev. 85 (1999); John B. Mitchell, Why Should Prosecutors Get the Last Word, 27 Amer. J. Crim. L. 139 (2000) (examines why a system that is constructed to favor the defendant gives the last word to the state); Patricia Puritz \& Katayoon Majd, Ensuring Authentic Youth Participation in Delinquency Cases: Creating a Specialized Paradigm for Juvenile Defense Practice, 45 Fam. Ct. Rev 466 (2007) (describing how juvenile defense attorneys must challenge racial, class and gender injustices in the juvenile system).

9 The constitutional rights of juvenile defendants are a continuing cause for concern. For more on juvenile rights see Mary Berkheiser, The Fiction of Juvenile Right to Counsel: Waiver in the Juvenile Courts, 54 Fla. L. Rev. 577 (2002); Cecilia Espenoza, Good Kids, Bad Kids: A Revelation About the Due Process Rights of Kids, 23 Hatings Const. L.Q. 402 (1996). 
a case with a less than innocent client. The district attorney could not prove Jill was a prostitute and the court dismissed the petition. Was Jill any more innocent than Dana was guilty? The students became frustrated with representation because they did not know if Dana was a child lured and entrapped by vice detectives or if she was a provocative child-woman who went to a hotel room with strange men prepared to have sex in exchange for money. ${ }^{10}$

Reflecting on case rounds involving Jill and Dana's cases, I garnered that they wanted to know if either was innocent. We would discuss the weight of the evidence which was greater against Dana than Jill. In general, the students attempted to decipher culpability from police reports and their own investigations. After meetings with the clients, the defense team drew their conclusions. In both cases, the reports varied from Jill and Dana's version of events. The defense team embraced Jill's innocence while Dana's innocence was, at best, inconclusive. Dana received quality representation but the defense team was not enthralled.

When we discussed cases, a greater zeal was given to Jill's defense. Jill's case took on a greater urgency than Dana's. We had to win Jill's case. She was innocent. Dana's case meant a trial with seasoned and sullied Vice Squad detectives testifying about our worldly client's sexual conversation. Dana was more than likely guilty. Why did she insist on having a trial?

As a former public defender, I understood how one felt compelled by the urgency of representing innocent clients. ${ }^{11}$ No defense attorney wants to see an innocent person convicted of a crime. Nevertheless, as a public defender, I vowed zealous representation no matter the status of the client. Diligence is expected in representing any client. ${ }^{12}$ Zealous representation is a matter of

10 Representing teenaged prostitutes can be a complex task. Dana was the composite of both the exploited child-woman and the worldly teenaged prostitute. See Magnus Seng, Child Sexual Abuse and Adolescent Prostitution: A Comparative Analysis, 24 Adolescence 665 (1989).

11 See, e.g., Albert W. Alschuler, Implementing the Criminal Defendant's Right to Trial: Alternatives to the Plea Bargaining System, 50 U. Chi. L. Rev. 931, 932. 34 (1983); John L. Barkai, Accuracy Inquiries for All Felony and Misdemeanor Pleas: Voluntary Pleas but Innocent Defendants?, 126 U. Pa. L. Rev. 88, 88-90 (1977); Stephanos Bibas, Harmonizing SubstantiveCriminal-Law Values and Criminal Procedure: The Case of Alford and Nolo Contendere Pleas, 88 Cornell L. Rev. 1361, 1382-86 (2003); Josh Bower, Punishing the Innocent, 156 U. Pa. L. Rev. 1117 (2008); John G. Douglass, Fatal Attraction? The Uneasy Courtship of Brady and Plea Bargaining, 50 Emory L.J. 437, 444-52 (2001); Daniel Givelber, Punishing Protestations of Innocence: Denying Responsibility and Its Consequences, $37 \mathrm{Am}$. Crim. L. Rev. 1363, 1364-71, 1384 (2000); Kenneth Kipnis, Criminal Justice and the Negotiated Plea, 86 Ethics 93, 97-100 (1976); Laurie L. Levenson, Police Corruption and New Models for Reform, 35 Suffolk U. L. Rev. 1, 42 (2001); David Lynch, The Impropriety of Plea Agreements: A Tale of Two Counties, 19 Law \& Soc. Inquiry 115, 132 (1994); Kevin C. McMunigal, Disclosure and Accuracy in the Guilty Plea Process, 40
Hastings L.J. 957, 986-90 (1989); Stephen J. Schulhofer, Criminal Justice Discretion as a Regulatory System, 17 J. Legal Stud. 43, 52 (1988); Stephen J. Schulhofer, Plea Bargaining as Disaster, 101 Yale L.J. 1979, 1992 (1992); Abbe Smith, Defending the Innocent, 32 Conn. L. Rev. 485, 494 (2000); Katherine J. Strandburg, Deterrence and the Conviction of Innocents, 35 Conn. L. Rev. 1321, 1336 (2003); Fred C. Zacharias, Justice in Plea Bargaining, 39 Wm. \& Mary L. Rev. 1121, 1151-55 (1998).

12 See ABA Ctr. for Prof'l Responsibility, Model Rules of Prof'l Conduct R. 1.3 (Diligence in the Client-Lawyer Relationship). "A lawyer shall act with reasonable diligence and promptness in representing a client." See also Michelle Craven \& Michael Pitman, To the Best of One's Ability: A Guide to Effective Lawyering, 14 Geo. J. Legal Ethics 983. Contra Anita Bernstein, The Zeal Shortage, 34 Hofstra L. Rev. 1165 (2006). 
Deconstructing Innocence: Reflections from a Public Defender: Can student attorneys accept the paradigm of guilt and continue zealous representation?

personal choice. ${ }^{13}$ My philosophy in the juvenile clinic was that innocence did not matter but quality representation did.

I did not want the student attorneys or social workers becoming emotionally or morally invested in innocent clients. They would extend more time and energy to the Jills of the world when the Danas are in true need of zealous representation. I inquired of the team why was innocence more compelling? I redirected the team to the idea that the more compelling case may be a teenaged prostitute who is guilty and who may have contemplated sex with strange men in hotels. Such cases are representative of girls who come from abusive, dysfunctional backgrounds and needed extra care. Innocence could not become more important than the need for client-centered representation. I was in a quandary as to why innocence dominated case round discussions and the defense team focus. Why had innocence become the lynchpin of receiving zealous defense? The rise of the importance of innocence in criminal defense has a tragic history.

\section{Innocence Paradigm}

Circumstances in the State of Illinois came to underpin the importance of the innocence movement. Illinois exonerated more death row inmates than they executed since the death penalty was reinstituted in 1977. ${ }^{14}$ Anthony Porter was two days from being executed by the state of Illinois for a double murder but was eventually exonerated by the Gov. George Ryan. ${ }^{15}$ Gov. Ryan

13 I define zealous representation as the ability to give quality representation to any client no matter what the charge or whether the client maintains his or her innocence or is guilty of the crime(s) charged. See also Sylvia Steven, Whither Zeal? Defending Zealous Representation, 65 Or. St. B. Bull. 27 (2005). Stevens laments the lack of the requirements of zealous representation by the ABA Model Rules of Professional Conduct and the Oregon State Bar rules. Id. Stevens defines zealous representation as "doing your best and being dogged in pursuit of the client's aims within the bounds of the law and the ethical rules. It is compatible with civility and courtesy and, in my humble opinion, the highest manifestation of professionalism." Id. at 28.

14 In 1972, the U.S. Supreme Court held in Furman v Georgia, 408 U.S. 238 (1972), the imposition of the death penalty was arbitrary and inconsistent and violated the Eighth and Fourteenth Amendments of the U.S. Constitution. A moratorium against the death penalty remained in effect until the 1977 decision in Gregg v. Georgia, 428 U.S. 153 (1976), that reinstated the use of the death penalty after states addressed the problems of arbitrary and capricious imposition.

15 See also David Horan, The Innocence Commission: An Independent Review Board for Wrongful Convictions, 20 N. Ill. U. L. Rev. 91, 94 (2000). See Ken Armstrong \& Steve Mills, Ryan Suspends Death Penalty, Chi. Trib., Jan. 31, 2000, at 1; Death Penalty Panel Is No PR Stunt, Chi. Trib., Apr. 8, 1999, at 18 ("The universal recognition-by all three branches of state government, plus a legal group-that there's something wrong with the death penalty process is a crucial and welcome step toward needed reform."); Death 'System' Does Not Work, Cap. Times (Madison, Wis.), Feb. 8, 1999, at 2C (reporting the call by the Chicago Tribune and the Chicago Sun-Times and legislators from both parties for a moratorium on executions in Illinois); Ray Long, Revamp Likely in Process for Death Penalty, Chi. Trib., May 18, 1999, at 20 (describing Illinois lawmakers as "scrambling to agree on how to revamp the state's death penalty procedures following several high-profile cases in which innocent men were released from Death Row"); Rick Pearson \& Gary Washburn, A Change of Heart on Execution Cases: In the Wake of Pressure After Anthony Porter's Release, Both Gov. Ryan and Mayor Daley Now See Serious Flaws in the DeathPenalty Process, Chi. Trib., Feb. 11, 1999, at 1 (noting that "the actions [of proposing reforms] by two lawand-order conservative Republicans add up to a political acknowledgment that the public's confidence in the death penalty has been shaken"); Don Thompson, Republicans Back Death Penalty Study, Chi. Daily Herald, Mar. 24, 1999, at 9 ("Two law-and-order suburban representatives plan today to join the push for a moratorium and study of what's wrong with the way Illinois administers the death penalty."). Anthony Porter's case, which resulted in his release on his own recognizance from death row on February 5, 1999, and the subsequent vacating of his murder convictions on March 11, 1999, Daniel Lehmann, Porter Cleared of '82 Murders, Chi. Sun-Times, Mar. 12, 1999, at 8, is both a horror story and a fairly representative 
proceeded to place a moratorium on administration of the death penalty in Illinois and removed all inmates from death row. ${ }^{16}$ Gov. Ryan's decision gave impetus not only to death penalty opponents but to the innocence movement. Barry Scheck and Peter Neufeld began the first Innocence Project at Cordozo Law School at Yeshiva University in 1992. ${ }^{17}$

The Innocence Project represented a different model than traditional clinics. The focus was on the claim of innocence and innocence that could be proven through DNA testing. ${ }^{18}$ The Innocence Project client generally had exhausted criminal appeals. ${ }^{19}$ The Innocence Network has assisted in freeing at least 218 wrongfully convicted persons since its inception, 16 from death row. ${ }^{20}$

(15 cont.) exemplar of a wrongful conviction, remarkable only for the success with which the miscarriage of justice was ultimately addressed. As in so many other cases, Porter's innocence was demonstrated by dedicated individuals outside of the criminal justice and court systems. See Jim Allen, Ex-Prisoner Praises Students Who Helped Free Him, Chi. Daily Herald, Feb. 6, 1999, at 9 (quoting Northwestern University journalism professor David Protess saying, "[T]he system was forced from the outside to recognize its injustice."'). Porter was convicted of a 1982 double murder. See Pam Belluck, Convict Freed After 16 Years on Death Row, N.Y. Times, Feb. 6, 1999, at A7. His case went through the state and federal courts' direct appeal and post-conviction review processes from the time of his conviction until March 1998. In September 1998, "two days before Mr. Porter was to be executed, his lawyers won a stay while a court considered a motion that Mr. Porter, who has an I.Q. of 51, was not competent enough to be put to death." Belluck, supra, A7. The extent of Porter's mental incapacity was only discovered at that late date because Porter's trial counsel had neither the experience nor the funding to investigate his case properly. Ken Armstrong, Bar Urges Changes in Capital Cases: Reforms Proposed To Give Defendants Better Trial Resources, Chi. Trib., Feb. 27, 1999, at 1 (describing Porter's trial attorney's financial inability "to do much, if any, pretrial investigation"). Therefore, "he [did not] establish[] that his client was mentally retarded - and thus without the requisite level of responsibility to merit the death penalty." Reforming Illinois' Death Penalty, Chi. Trib., Mar. 17, 1999, at 22.

"After that, [Northwestern University journalism professor David] Protess, who each semester assigns his class murder cases to re-investigate, gave his students the Porter case." Belluck, supra, at A7. These students, assisted by Professor Protess and a private investigator, thoroughly reinvestigated the case and discovered major discrepancies in the accounts of the murders, a confession by the main prosecution witness "[saying] he had been pressured during hours of questioning by the police to implicate Mr. Porter," and finally confessions from the actual murderer's wife and then the nowconfessed murderer himself, Alstory Simon, exonerating Porter. Belluck, supra, at A7.

Although the Illinois authorities never investigated any other suspect for the murders, see Eric Zorn, A Few Words Come to Mind for Death Row System, Chi. Trib., Feb. 9, 1999, at 1, Porter "maintained his innocence ever since the day of his arrest," through the course of over sixteen years in prison and a full array of capital appeals terminating with the Supreme Court's denial of certiorari on federal habeas corpus in March 1998. John Carpenter \& Alex Rodriguez, 'I'm Free': Wrongly Convicted of Double Murder, Porter off Death Row, Chi. SunTimes, Feb. 6, 1999, at 1; see also Porter v. Gilmore, 118 S. Ct. 1343 (1998) (denying petitions for rehearing on denial of certiorari).

Governor George Ryan pardoned Porter of the double murder on March 19, 1999, to assist in a claim for compensation for wrongful imprisonment from the state. See Governor Pardons Ex-Inmate Porter, Chi. Trib, Mar. 20, 1999, at 5. Alstory Simon eventually pleaded guilty to the double murder. See Tom Ragan, Years After Death Row, Travesty, Killer Gets Due, Chi Trib., Sept. 8, 1999, at 1. On September 20, 1999, prosecutors finally dropped armed robbery charges against Porter, stemming from the same night as the double murder for which Porter was convicted to death. See Monica Davey, Porter at Last Free of All Charges: Wrongly Sentenced To Die, He Awaits 2nd Pardon, Chi. Trib., Sept. 21, 1999, at 1.

16 See Governor Ryan Halts the Death Penalty Calls for Study of State's Messed-Up System, Chi. Trib., Feb. 8, 2000; Governor Commutes All Death Sentences, Chi. Trib., Jan. 11, 2003.

17 See Innocence Project, at http://www.innocence project.org/about/Mission-Statement.php [hereinafter Innocence Project](last visited Sept. 29, 2008).

18 Id.

19 Id.

20 The Innocence Project detailed that there are 220 post-conviction exonerations in United States' history with the average falsely convicted person serving a twelve-year sentence. Seventeen falsely convicted persons received death sentences before being exonerated. Innocence Project at http://www.innocenceproject.org/know/. 
Deconstructing Innocence: Reflections from a Public Defender: Can student attorneys accept the paradigm of guilt and continue zealous representation?

\section{Innocence in Clinical Legal Education}

In many jurisdictions Clinical education has become invaluable in training law students for the essentials of law practice. ${ }^{21}$ In the United States Clinical education is now an essential component of legal education. The Innocence projects have expounded on the clinical education model. Students have life changing experiences representing men and women exonerated after spending decades in prison and in some cases on death row. The Innocence Project has wielded great influence on clinical education. ${ }^{22}$ In particular, Keith Findley details the skills students develop in

21 See Legal Education and Professional DevelopmentAn Educational Continuum: Report of the Task Force on Law Schools and the Profession: Narrowing the Gap, 1992 A.B.A. Sec. Legal Educ. \& Admissions To The Bar. Xi, http://www.abanet.org/legaled/ publications/onlinepubs/maccrate.html\#B. $\% 20 \mathrm{Oy}$ erview $\% 20$ of $\% 20$ the $\% 20$ Skills $\% 20$ and $\% 20$ Value s\%20Analyzed [hereinafter MacCrate Report]. The report analyzes the fundamental lawyering skills essential for competent representation. It begins with two analytical skills that are conceptual foundations for virtually all aspects of legal practice: problem solving (Skill § 1) and legal analysis (Skill § 2). It then examines five skills that are essential throughout a wide range of kinds of legal practice: legal research (Skill $\S 3$ ), factual investigation (Skill § 4), communication (Skill § 5), counseling (Skill § 6), and negotiation (Skill § 7). The statement next focuses upon the skills required to employ, or to advise a client about the options of litigation and alternative dispute resolution (Skill § 8). Although there are many lawyers who do not engage in litigation or make use of alternative dispute resolution mechanisms, even these lawyers are frequently in a position of having to consider litigation or alternative dispute resolution as possible solutions to a client's problem, or to counsel a client about these options, or to factor the options into planning for negotiation. To accomplish these tasks, a lawyer needs to have at least a basic familiarity with the aspects of litigation and alternative dispute resolution described in Skill $\S 8$. Skill $\S 9$ identifies the administrative skills necessary to organize and manage legal work effectively. This section reflects the perception that adequate practice management skills are an essential precondition for competent representation of clients. Finally, Skill $\S 10$ analyzes the skills involved in recognizing and resolving ethical dilemmas. Id.

22 See Keith A. Findley, The Pedagogy of the Innocent: Reflections on the Role of Innocence Projects in Clinical Legal Education, 13 Clinic L. Rev. 231 (2006) [hereinafter Findley, Pedagogy]; Barry Scheck, Peter Neufeld \& Jim Dwyer, Actual Inncence: Five days to Execution, and other Dispatches from the Wrongly Convicted (2000); George H. Ryan, Report of the Governor's Commission on Capital Punishment (Apr. 15, 2002), http://www.idoc.state. il.us/ccp/ccp/reports/index.html; Innocence Commission for Virginia, A Vision for Justice (2005), available at http://www.icva.us/; Gary L. Wells et al., Eyewitness Identification Procedures: Recommendations for Lineups and Photospreads, 22 Law \& Hum. Behav. 9 (1998); Thomas P. Sullivan, Police Experiences with Recording Custodial Interrogations, Special Report, NW. U. Sch. L., Center on Wrongful Convictions (Summer 2004); Steven A. Drizin \& Richard A. Leo, The Problem of False Confessions in the PostDNA World, 82 N.C. L. Rev. 991 (2004); Richard A. Leo \& Richard J. Ofshe, The Consequences of False Confessions: Deprivations of Liberty and Miscarriages of Justice in the Age of Psychological Interrogation, 88 J. Crim. L. \& Criminology 429 (1998); Gail Johnson, False Confessions and Fundamental Fairness: The Need for Electronic Recording of Custodial Interrogations, 6 B.U. Pub. Int. L.J. 719 (1997); Steven A. Drizin \& Beth A. Colgan, Let the Cameras Roll: Mandatory Videotaping of Interrogations Is the Solution to Illinois' Problem of False Confessions, 32 Loy. U. Chi. L.J. 337 (2001); Keith A. Findley, Learning from Our Mistakes: A Criminal Justice Study Commission To Study Wrongful Convictions, $38 \mathrm{Cal}$. W. L. Rev. 333 (2002); Michael J. Saks et al., Toward a Model Act for the Prevention and Remedy of Erroneous Convictions, 35 New Eng. L. Rev. 669 (2001); Sharone Levy, Righting Illinois' Wrongs: Suggestions for Reform and a Call for Abolition, $34 \mathrm{~J}$. Marshall L. Rev. 469 (2001); Steven Clark, Procedural Reforms in Capital Cases Applied to Periury, 34 J. Marshall L. Rev. 453 (2001); Michael J. Saks \& Jonathan J. Koehler, What DNA "Fingerprinting" Can Teach the Law About the Rest of Forensic Science, 13 Cardozo L. Rev. 361 (1991); George Castelle, Lab Fraud: Lessons Learned, The Champion, May 1999 at 12; Scott Bales, Turning the Microscope Back on Forensic Scientists, 26 Litig. 51 (2000); U.S. Dep't of Justice, Office of Justice Programs, National Institute of Justice, A Report from the National Commission on the Future of DNA Evidence, Postconviction DNA Testing: Recommendations for Handling Requests (1999), http:/www.ojp.usdoj. gov/nij/pubssum/177626. htm.; Rob Warden, The Snitch System, NW. U. Sch. L., Center on Wrongful Convictions (Winter 2004-2005), available at http:// www.law.northwestern.edu/wrongfulconvictions/d ocuments/SnitchSystemBooklet.pdf; Daniel Givelber, Meaningless Acquittals, Meaningful 
representing clients in wrongful conviction cases:

"Innocence projects offer particularly good opportunities for learning about the importance of facts; about the importance of being skeptical, vigilant, and thorough; about ethics, values, and judgment; and about the criminal justice system itself - from obtaining a critical perspective on legal doctrine to a critical understanding of 'the law in action,' that is, how the criminal justice system actually works, and how it might be made to work more effectively and fairly." 23

The valuable work of Innocence Projects can be measured by the many reforms instituted in the criminal justice system after highlighting the plight of the wrongfully convicted. ${ }^{24}$ The media has also become a key player in the portrayal of the wrongfully convicted person. The American public can watch in real time as a prison releases a wrongfully convicted man or woman after decades of imprisonment. ${ }^{25}$ The portrayals of release are emotional and they strike a chord with the American public. The cases, the narratives and the images of the innocent leave an effect on our collective psyche. An unintended consequence however may be the focus on the importance of innocence.

(22 cont.) Convictions: Do We Reliably Acquit the Innocent?, 49 Rutgers L. Rev 1317 (1997); Brandon L. Garrett, Innocence, Harmless Error, and Federal Wrongful Conviction Law, Wis. L. Rev. 35 (2005); Stanley Z. Fisher, Convictions of Innocent Persons in Massachusetts: An Overview, 12 B.U. Pub. Int. L.J. 1 (2002); Myrna Raeder, What Does Innocence Have To Do With It? A Commentary on Wrongful Convictions and Rationality, Mich. St L. Rev. 1315 (2003); Daniel S. Medwed, The Zeal Deal: Prosecutorial Resistance to Post-Conviction Claims of Innocence, 84 B.U. L. Rev. 125 (2004); Richard A. Rosen, Reflections on Innocence, Wis. L. Rev. 237 (2006); Keith A. Findley \& Michael S. Scott, The Multiple Dimensions of Tunnel Vision in Criminal Cases, Wis. L. Rev. 291 (2006); Peter A. Joy, The Relationship Between Prosecutorial Misconduct and Wrongful Convictions: Shaping Remedies for a Broken System, Wis. L. Rev. 399 (2006); Richard A. Leo et al., Bringing Reliability Back In: False Confessions and Legal Safeguards in the Twenty-First Century, Wis. L. Rev. 479 (2006); Mary Prosser, Reforming Criminal Discovery: Why Old Objections Must Yield to New Realities, Wis. L. Rev. 541 (2006); Gary L. Wells, Eyewitness Identification: Systemic Reforms, Wis. L. Rev. 615 (2006); Katherine R. Kruse, Instituting Innocence Reform: Wisconsin's New Governance Experiment, Wis. L. Rev. 645 (2006); Rodney Uphoff, Convicting the Innocence: Aberration or Systemic Problem?, Wis. L. Rev. 739 (2006).

23 See Findley, Pedagogy, supra note 22, at 241. Findley quotes Dean Ken Davis in describing "law in action" as the concept of the legal educational philosophy at the University of Wisconsin Law School. As Dean Davis has explained, Wisconsin has a tradition of focusing its scholarship and teaching on "law in action," the concept that "in order to truly understand the law, you need not only to know the 'law on the books,' but also to look beyond the statutes and cases and study how the law plays out in practice." Dean Davis has written, "'Law in Action' reminds us that no matter how interesting or elegant the theory or idea, we always need to ask, "Why should this matter to people in the real world?"' Kenneth B. Davis, Law in Action: The Dean's View, available at www.law.wisc.edu/Davislawinactionessay.htm at 1 .

24 See Innocence Project, supra note 17, available at http://www.innocenceproject.org/fix/FalseConfessions.php. The Innocence Project reports that the recording of interrogations reduces the likelihood of false confessions. The Supreme Courts of Alaska and Minnesota have declared that, under their state constitutions, defendants are entitled as a matter of due process to have their custodial interrogations recorded. In 2003, Illinois became the first state to require by law that all police interrogations of suspects in homicide cases must be recorded. Police departments in Broward County (Florida) and Santa Clara County (California), among others, have begun to record interrogations without a law requiring them. Proactive policies like these have been adopted because the practice benefits police and prosecutors as well as innocent suspects. Id.

25 See Elliot C. McLauglin, Convicted by Doodles, Masters Is Freed by DNA, Jan. 25, 2008, available at http://www.cnn.com/2008/CRIME/01/22/masters.ca se/index.html\#cnnSTCText 


\section{Deconstructing Innocence}

\section{Fundamental Question}

Has the emphasis on innocence of late created a category of clients that have been deemed more worthy of zealous representation? No one deserves greater representation than does the wrongfully convicted who did not receive it and paid the costs with their freedom. The Illinois Commission on the death penalty cited inadequate representation as one of the major problems of how the innocent become convicted of crimes they did not commit. ${ }^{26}$ The potential problem becomes the emphasis on the person who was wrongfully convicted and not on the system that allowed an innocent person to be convicted.

The narratives of the wrongfully convicted persons are riveting. ${ }^{27}$ Spending decades in prison and potentially having exhausted all appellate remedies, the Innocence Project has been the only hope for many. The Innocence Project has also been the catalyst for criminal justice reform. ${ }^{28}$ Critics however, note that the focus on innocence in the media and government creates an unintended consequence of innocence being the exclusive reason for reform or zealous representation. ${ }^{29}$ Innocence can be a dual-edged sword. The focus on innocence brought needed attention to a troubled system but it has also been used as a gate keeping function in federal courts. The focus on innocence created procedural and substantive problems. The courts and Congress used innocence as a procedural bar and severely limited access to grant habeas review in the name of innocence. Innocence has a profoundly negative impact on non-innocence substantive issues such as justification defenses and constitutional violations.

\section{The Procedural Problem and The Original Innocence Movement}

Carol Steiker and Jordan Steiker extrapolate that the first innocence movement began after the Warren court introduced expansive treatment of collateral federal review of state court convictions as a vehicle for the consideration of all federal constitutional claims in a federal

26 George H. Ryan, Governor, Report of the Governor's Commission on Capital Punishment, 108 (Apr. 15, 2002), http://www.idoc.state.il.us/ccp/ccp/reports/ commission_report/chapter_07.pdf. See also Ken Armstrong and Steve Mills, The Failure of the Death Penalty in Illinois, Part 2: Inept Defenses Cloud Verdict (Nov. 15, 1999), http://www.chicagotribune.com/ news/specials/chi-991115deathillinois2,0,721147. story.

27 See Jim Dwyer, Peter Neufeld \& Barry Scheck, Actual Innocence: Five days to Execution and Other Dispatches from the Wrongfully Convicted (2000).

28 The Innocence Project has a series of priority issues that would assist in fixing the system including: eyewitness identification, false confessions, DNA testing access, evidence preservation, forensic oversight, innocence commissions and exoneree compensation. Innocence Project, http://www.innocenceproject.org/fix/PriorityIssues.php. The Innocence Project also assisted in federal legislation, the Justice For All Act of 2004, Public Law 108-405,108th Congress. The purpose of the Act is to protect crime victims' rights, to eliminate the substantial backlog of DNA samples collected from crime scenes and convicted offenders, to improve and expand the DNA testing capacity of federal, state, and local crime laboratories, to increase research and development of new DNA testing technologies, to develop new training programs regarding the collection and use of DNA evidence, to provide post-conviction testing of DNA evidence to exonerate the innocent, to improve the performance of counsel in state capital cases, and for other purposes. Available at http://www.govtrack.us/congress/billtext.xpd?bill=h 108-5107.

29 See infra notes 30-48. See also Brandon L. Garrett, Judging Innocence, 108 Colum. L. Rev. 55 (2008); Daniel Medwed, Innocentrism, 2008 U. Ill. L. Rev. 1549 (2008); Andrew M. Siegel, Moving Down the Wedge of Injustice: a Proposal for Third Generation Wrongful Conviction Scholarship and Advocacy, 42 Amer. Crim. L. Rev. 1219 (2005). 
forum. ${ }^{30}$ Paradoxically, actual innocence became a narrowing avenue for appellate review in reaction to the Warren Court.

The Supreme Court guided by Justices Burger and Rehnquist limited the substantive scope of federal habeas review. ${ }^{31}$ The Court emphasized innocence as a limiting criterion. ${ }^{32}$ The Court precluded re-litigation of Fourth Amendment claims rationalizing that it would impede claims rather than promote the accuracy of criminal verdicts. ${ }^{33}$ The Court proceeded to preclude "new" constitutional claims and allowed only narrow exceptions. ${ }^{34}$ Lastly, the Court relaxed the standard for finding constitutional errors. The Court allowed findings of harmless on habeas review, determining that only truly grievous constitutional wrongs - conviction of the innocent being the paramount case- should be corrected on habeas. ${ }^{35}$

Congress added legislation to the first innocence movement by amending the federal habeas statute in the Antiterrorism and Effective Death Penalty Act of 1996 (AEDPA). ${ }^{36}$ Congress crafted an innocence exception that relied exclusively on factual innocence. ${ }^{37}$ The law required that the petitioner prove such factual innocence by "clear and convincing evidence" as opposed to the previous and more lenient "more likely than not" evidentiary standard. ${ }^{38}$ The use of factual innocence as the essential factor for review established two governmental paradigms: 1) acknowledgement of innocent persons being convicted and 2) the use of factual innocence to limit

30 Carol Steiker \& Jordan Steiker, The Seduction of Innocence: The Attraction and Limitation of the Focus on Innocence in Capital Punishment Law and Advocacy, 95 J. Crim. L. \& Criminology 587, 609 (2005) [hereinafter Steiker \& Steiker]. The authors note that in response to the Warren Court's incorporation of the criminal procedure provisions of the Bill of Rights, its expansive reading of those provisions, and its liberal approach toward the availability of federal review of state court convictions, the Burger and Rehnquist Courts moved in the 1970s and 1980s to craft rules of constitutional adjudication in the criminal process to focus on truth-seeking rather than vindication of constitutional rights per se. Id.

31 Id. citing Wainwright v. Sykes, 433 U.S. 72 (1977) (excuse for petitioner's failure to comply with state procedural rule must meet "cause and prejudice" standard rather than "deliberate bypass" standard of Fay v. Noia, 372 U.S. 391 (1963)); Keeney v. Tamayo-Reyes, 504 U.S. 1 (1992) (applying "cause and prejudice" standard to failure to develop the facts underlying claim) (overruling Townsend $v$. Sain, 372 U.S. 293 (1963)); McCleskey v. Zant, 499 U.S. 467 (1991) (applying "cause and prejudice" standard to new claims not presented in previous petition); Kuhlmann v. Wilson, 477 U.S. 436 (1986) (applying "cause and prejudice" standard to successive claims raising grounds identical to grounds heard and decided on the merits in a previous petition).

32 The authors note that the Court in McCleskey Zant, Murray v. Carrier and Kuhlmann v. Wilson decisions crafted a narrow "miscarriage of justice" exception to the "cause and prejudice" requirement, allowing petitioners to raise successive claims, repetitive new claims, or defaulted claims if they made a colorable showing of actual innocence of the underlying crime. See McCleskey v. Zant, 499 U.S. 467 (1991) (repetitive new claims); Murray v. Carrier, 477 U.S. 478 (1986) (defaulted claims); Kuhlmann v. Wilson, 477 U.S. 436 (1986) (successive claims); see also Sawyer v. Whitley, 505 U.S. 333 (1992) (crafting an even narrower "innocent of the death penalty" miscarriage-of-justice exception).

33 Steiker \& Steiker, supra note 30, at 610, citing Stone v. Powell, 428 U.S. 465 (1976) (denied granting relief based on Fourth Amendment claim litigated at trial).

34 Id., citing Teague v. Lane, 489 U.S. 288 (1989)(barred relief based on state rule that was not established during the state decision).

35 Id., citing Brecht v. Abrahamson, 507 U.S. 619 (1993)(relaxed the constitutional standards for harmless error from beyond a reasonable doubt to whether error had substantial and injurious effect).

36 Id. at 611, citing Pub. L. No. 104-132, 110 Stat. 1214 (1996) (codified as amended in scattered sections of 28 U.S.C.).

3728 U.S.C. $\$ 2244($ b)(2)(B)(ii).

38 Steiker \& Steiker, supra note 30, at 610, citing Murray v. Carrier, 477 U.S. 478, 496 (1986). The Court imposed a "clear and convincing" standard of proof only on defendants seeking to show that they were ineligible for the death penalty, rather than innocent of the underlying offense. See also Sawyer, 505 U.S. at 336. 
all other claims including those of a constitutional nature. Steiker and Steiker postulate that judicial and legislative re-calibration of federal habeas corpus relief was part of a larger movement to accurate determination of guilt or innocence which became the only value in constitutional criminal procedure. ${ }^{39}$

Congress and the federal courts used innocence to limit access of defendants to the courts. A study completed by the U.S. Department of Justice reiterates Steiker and Steiker's findings. The implementation of the AEDPA reduced the number of evidentiary hearings granted based on habeas petitions by half. ${ }^{40}$ Using innocence as the impetus for change had a chilling effect in capital habeas cases. ${ }^{41}$

\section{Substantive Problems with Innocence}

The emphasis on factual innocence undermines traditional approaches to criminal defense. The focus on wrongful convictions creates what Margaret Raymond quantifies as a "supercategory of innocence". ${ }^{42}$ Factual innocence is elevated over other categories of innocence. ${ }^{43}$ At trial, the jury must determine whether there is sufficient evidence to determine guilt. ${ }^{44}$ The defendant does not bear the burden of proving factual innocence or the legally presumed innocence guaranteed by the constitution. ${ }^{45}$ The cultural and legal focus on factual innocence may lead juries to conclude that evidence short of factual innocence does not justify an acquittal. ${ }^{46}$

The constitutional rights of defendants will become secondary to innocence determinations. The focus on innocence subverts the concern criminal defense litigators have about protecting defendants' constitutional rights and launching challenges to illegal search and seizures. ${ }^{47}$ Constitutional claims of guilty defendants lack the visceral appeal of innocence claims. ${ }^{48}$

\section{Conclusion}

The innocence movement has proven invaluable in bringing attention to a myriad of problems in the criminal justice system. The revelation and poignant freeing of wrongfully convicted persons has influenced legislative and court reforms. Criminal defense attorneys and prosecutors are being held to more stringent standards. The innocence movement has revolutionized clinical legal education as well. Student attorneys engage in life altering cases and in instances such as Anthony

39 Steiker \& Steiker, supra note 30, at 612.

40 Nancy King, Fred Cheesman, \& Brian Ostrom, Executive Summary: Habeas Litigation in U.S. District Courts: An Empirical Study of Habeas Corpus cases Filed by State Prisoners under the Antiterrorism and Effective Death Penalty Act of 1996, Nat'l Inst. Just., Office of Justice Programs, U.S. Dep't of Justice, Aug. 21, 2007, at 5.

41 See Todd E. Pettys, Killing Roger Coleman: Habeas, Finality and the Innocence Gap, $48 \mathrm{Wm}$. \& Mary L. Rev. 2313 (2007) (discussing the innocence gap created in habeas procedures - a gap between the amount of exculpatory evidence sufficient to thwart finality of habeas petition versus the amount of exculpatory evidence sufficient to persuade a federal court to forgive petitioners procedural mistakes and review based on the constitutional merits).
42 Margaret Raymond, The Problem with Innocence, 49 Clev St. L. Rev. 449, 457 (2001).

43 Id.

44 Id.

45 Id.

46 Id.

47 See Medwed, supra note 29, at 1556, citing Linda J. Skitka \& David A. Houston, When Due Process Is of No Consequence: Moral Mandates and Presumed Defendant Guilt or Innocence, 14 J. Int'l Soc'y Just. Res. 305, 323 (2001) (presenting results of empirical studies from psychologists that suggest people tend to disregard due process values when they believe they know the defendant to be guilty or innocent).

48 Id. 
Porter's case actually save peoples' lives. As the students learn to engage in a flawed system they also need to grasp that some clients are guilty. Quality representation should never be reduced to essentialist standards of guilt or innocence. Zealous representation should never be married to the importance of innocence. The flaws in the criminal justice system that convict the innocent also taint the guilty. Jill and Dana represent a cautionary tale of the attractiveness of innocence. I diligently guard against being seduced by innocence. Innocence should never replace the foundations of zealous representation. Jill and Dana deserved engaged and zealous student attorneys no matter their status. 
